\title{
COMPARATIVE PROFESSIONAL EDUCATION IN UKRAINE: CURRENT STATE, CHALLENGES, PROSPECTS
}

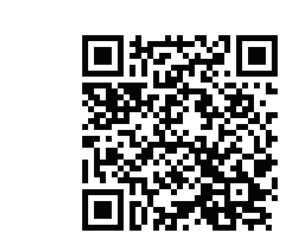

To cite this article:

\author{
Svitlana Sysoieva, Dr. Sc., Prof. \\ Academician-Secretary, \\ Department of General Pedagogy and Philosophy of Education, \\ National Academy of Educational Sciences of Ukraine, \\ Kyiv, Ukraine \\ 2099823@gmail.com \\ https://orcid.org/0000-0003-2499-732X
}

\begin{abstract}
Sysoieva, S. (2018). Comparative professional education in Ukraine: current state, challenges, prospects. Education: Modern Discourses, 1, 43-54. https://doi.org/10.32405/2617-3107-2018-1-5
\end{abstract}

\begin{abstract}
The article presents a quantitative and qualitative analysis of comparative studies on professional education in Ukraine since independence (1991); the consideration of the concept of "comparative professional education", the main provisions of its methodology; the analysis of the tasks and specifics of comparative studies in the field of professional education. The article shows that the specificity of comparative professional education requires an interdisciplinary approach to research, taking into account external factors (historical, social, cultural, economic, political, etc.) of influence on the system, tendencies, content, technology, forms and methods of professional education in foreign countries that is possible to carry out on the principles of Educology.
\end{abstract}

Key words: comparative professional education; comparative study; comparison criteria; Educology; interdisciplinary approach; monographic research.

\section{INTRODUCTION. PROBLEM STATEMENT}

The development of Ukraine since 1991 as an independent democratic state has required significant changes in all spheres of society's life, in particular the sphere of education, as the most influential not only on the formation of social consciousness, but also on the socio-economic development of the country. The processes of globalization, European integration intentions of Ukraine, and informatization of society have reinforced the need to reform and modernize the education system not only in accordance with the requirements of the European educational and research space, but also the transformational processes in the Ukrainian economy, which has gradually become more and more marketenised. Economic development of the country required the appropriate training of specialists in vocational and higher education, able to meet the needs of the labor market. In such circumstances, studies of comparative education, in particular comparative professional education, aimed at studying the experience of the developed countries with regard to professional training of specialists of all levels, are of particular importance. 
It should be noted that comparative education is a young branch of educational science in Ukraine, which has been actively developing since the independence, when studying the experience of the most developed countries in the field of education, its application in Ukraine, taking into account its traditions and history, became an urgent need of time.

The first studies on comparative professional education were done and published in Ukraine in 1995. Generally, since the years of independence in Ukraine more than 320 dissertations on comparative education topics have been defended, in particular, in the specialties "General Pedagogy and History of Pedagogy" (13.00.01) - 147; "Theory and Methods of Professional Education" (13.00.04) - 166; "Theory and Methods of Upbringing" (13.00.07) -3 .

Comparative professional education is an integral part of comparative education, within which comparative studies are conducted on professional education, foreign experience of different aspects of professional training of specialists is studied (within the specialty: "Theory and Methods of Professional Education" - 13.00.04). Such studies cover not only the study of the content, organizational forms, methods and modern technologies of professional training of specialists, but also the tendencies of formation and development of professional training of specialists in foreign countries, historical features of such formation and development, factors of influence.

It should be noted that among all defended dissertations there are over 47 doctoral studies, more than $270 \mathrm{PhD}$ researches. Doctoral dissertations were defended in two specialties: 13.00.01 and 13.00.07.

Doctoral dissertations on comparative education are about $15 \%$ of the total number of studies. As for comparative professional education, doctoral dissertations are about $13 \%$ of the total number of defended ons.

Distribution of defended dissertations over the years is heterogeneous: $1995-2$; 1996 - 3; 1997 - 1; 1998 - 6; 1999 - 1; 2000 - 11;2001 - 10; 2002 - 6; 2003 - 9; 2004 - 17; 2005 - 20; 2006 - 16; 2007 - 11; 2008 - 37; 2009 - 23; 2010 - 22; 2011 - 43; 2012 - 20; 2013 - 14; 2014 - 16; 2015 - 14; 2016 - 9; 2017 - 6; 2018 - 2 (as of Sept. 2018).

As we can see, the largest number of comparative studies was defended from 2004 to 2015 , the time for active modernization of education in Ukraine, the preparation of new laws in the field of education and science, concepts, etc. As for comparative professional education, research in this area has actively started since 2011.

The joining of Ukraine to the Bologna process, the intentions to integrate into the European educational and research space, the need to develop a national qualifications framework at various stages have increased the focus on the study of foreign expertise in professional training. At the same time, there is a lack of a holistic quantitative and qualitative analysis of the comparative studies on professional education in Ukraine for the years of independence (since 1991), the challenges faced by this young branch of pedagogical science and the prospects for its development. Actually, this is the purpose of this article.

\section{LITERATURE REVIEW}

Significant contribution to the development of comparative education in Ukraine, its methodology was made by L. P. Pukhovska (1998), A. A. Sbruieva (2005), O. I. Lokshyna (2011), M. P. Leshchenko (1996), T. M. Desyatov (2006), O. I. Ogienko (2009), A. V. Vasilyuk (2011), T. Y. Kristopchuk (2014) and others. 
The first pioneering research on comparative professional education was the study of the doctoral level of Maria Petrivna Leshchenko on the topic "Teacher Training Technology for Aesthetic Education Abroad (on materials of Great Britain, Canada, USA)" (1996) and Lyudmila Prokopivna Pukhovskaya on the theme: "Professional Training of Teachers in the Countries of Western Europe in the Second Half of the 20th Century" (1998). These studies laid the foundation for further doctoral studies on various aspects of teacher training, namely: "Professional Development of Secondary School Teachers in the Systems of Continuing Education in the United Kingdom, Canada, USA" (Mukan, 2011), "The System of Vocational Training of High School Teachers in the United States of America" (Shandruk, 2013), "Theoretical and Methodological Principles for Future Primary School Teachers Training in Polish Higher Educational Institutions by Multimedial Technologies" (Kucha, 2016).

Scientific contributions to the development of the methodology of comparative professional education research have also been made by Polish researchers who defended the dissertations of the doctoral (habilitation) level in Ukraine. In particular, this is a study by Grzegorz Kedrovicz "Theory and Practice of Computer Technologies in Polish and Polish Professional Education Institutions" (2001), Iolanti Schempuch, "Trends in Teacher Education in Poland (1918-1999)" (2001), Janusz Moritz "The System of Teacher Training and Ways of its Optimization in the Context of the Development of Modern Education in Poland" (2004).

\section{METHODOLOGY}

In comparative pedagogical studies we distinguish general, special and specific dimensions. The general one we refer to the methodological foundations on which each educational research is based. The Special one referres to the methodology of the comparative study. Specific or individual, in our opinion, can be attributed to the phenomenon under study, which can reflect various branches of educational science (professional education, didactics, theory and method of education, social pedagogy, etc.) and is the subject of research.

Analyzing the problems of comparative education as a science, it is worthwhile to highlight those that are invariant for each comparative study. To such tasks-invariants it is necessary to attribute (Sysoieva, 2015):

- The task of thorough analysis of the content of the concepts used in the study and are concepts that are translated from a foreign language, a careful comparison of their content with the content of concepts used in the national educational space.

- The ambiguous interpretation of the concepts used today in the world and the European educational space, the lack of their adaptation to the traditional notions of the Ukrainian educational science causes great harm to the development of the educational field of the country, makes ambiguity in understanding terminology, generates communicative chaos from academics and practitioners, reduces the level of methodology of educational science. That is why we believe that a comparative study should begin with an analysis and comparison of the thesaurus: the domestic and the country of study.

- The task of realizing a comparison itself, since the purpose of any comparative study, as it does not sound paradoxically in this context, should be the comparison procedure. 
- It is worth noting that comparative studies in Ukraine have not yet fully gained comparative status. There is lack of proper comparative research. Quite often, conducted studies deal with foreign education having the character of simple descriptions with recommendations on transfering experience to Ukraine. This, in our opinion, is connected with the formation of comparative education in Ukraine, with the "age" of this, even young, field of knowledge.

- The task of determining the criteria for comparison, the description of the stages and methodology of the study, which includes the demonstration of equivalence, comparability of the phenomenon under study in different countries.

- The task of the possibility and expediency of transferring the studied experience of education, models of education of other countries in Ukraine.

- The task of developing recommendations for educational policy, the content of reforms and the modernization of education, which, in essence, is the goal of any comparative study.

- Such tasks, in our opinion, should be defined as methodological-normative. The value of each comparative study, including the professional comparative education, is determined by the fulfillment of these tasks.

It should be noted that in recent years in the Ukrainian educational space there have been educational programs with the methodology of conducting comparative studies, taking into account the experience of European countries, in particular the program "Comparative Education” (2014), "Methodology of Comparative Research in Education” (2018).

\section{MAIN RESULTS}

We will analyze the topics of defended dissertations on comparative professional education. The largest number of studies was devoted to various aspects of teacher training (51), which in our view was related to the transformational processes that took place in general secondary education during the years of independence and which led to a fundamental reform of the Ukrainian school today.

The researchers also paid attention to the problems of training students of various specialties in the humanitarian sphere (lawyers, managers, civil servants, specialists in international relations, environmentalists, philologists and linguists, economists) 24; the aspect of standardization, reformation and development of education (14), in particular professional (7); training of specialists, in particular, social pedagogy and social work (12), foreign language (10), tourism (9), technical disciplines (3), pre-school education (3), production personnel (2), agrarian sector (5), border Service (1), medical (5). It should be emphasized that the problems of pre-vocational training at high school (2), training of adults in education (2), experts in education (2), vocational training of vulnerable groups (unemployed, immigrant) (2), training and postgraduate education (4), vocational training (3), etc.

It should be noted that the most selected countries for the study were EU member states, in particular: France, Great Britain, Germany, Poland, Sweden, Spain, Finland, Greece, the Netherlands. Considerable attention was also paid to the study of various aspects of training in the United States and Canada. Individual studies were conducted based on such countries as China, Mexico, Australia, Japan. Significantly less systematic research was carried out on the problems of professional training of specialists in general in the European Union, Western Europe, Eastern Europe, etc. 
The impactful comparative professional studies of a doctoral level conducted on the examples of several countries of the European Union are the following:

1) "Development of Vocational Education and training in Germany (late XIX - XX)" (Abashkina, 1999), which explores the socio-pedagogical principles of the development of vocational education and training (VET) in Germany, determine the overall mechanism for its implementation and functioning as a coherent system that guarantees the training of highly skilled competent specialists;

2) "The Development of Skilled Workers Training Systems in Bulgaria and Poland (end of the 19-20-th centuries)" (Kaplun, 2011), which presents a holistic comparative and pedagogical analysis of the development of training systems for skilled workers in Bulgaria and Poland, the tendencies and peculiarities of the development of VET systems of the countries, their management at different historical stages, improvement of content, principles, functions and scientific and methodological support of activity of VET schools of different types, and the influence of balancing and integration processes for the transformation of national VET systems in Bulgaria and Poland under the conditions of the European Union. In this study, similar and different in the development of training systems for skilled workers in Bulgaria, Poland and Ukraine are educed. The possibilities of using progressive ideas in the experience of skilled workers training of Bulgaria and Poland under the conditions of modernization of VET system in Ukraine taking into account progressive ideas of European integration processes are described;

3) "Teachers of Physical Education Training in Poland for the Assessment of Students Learning Outcomes" (Mushketa, 2007), which based on the generalization of Polish experience, the theoretical and methodological principles of modernizing the technology for evaluating students' achievements in the professional activity of the teacher of physical education, as well as in the system of its preparation, the concept, technology and criteria for assessing the academic achievements of students as a component of the didactic measurement on its quantitative and qualitative components, the system of preparation Teachers of Physical Education to Assess Teaching Achievements of Students.

4) "Theory and Practice of Teacher Education for Pedagogical Communication in Higher Education Institutions in Germany" (Chulkova, 2010), which defines the main directions of development of the teacher's communicative competence, proposes a model of professional communication of the teacher as a factor of normative communicative activity with its own structure, goals, means, motives, content, functions, principles, aimed at the successful socialization of students.

Among the comparative professional education studies dedicated to the United States we should focus on the following:

1) "The Theory and Practice of Professional Education for the Unemployed in the USA" (Bidyuk, 2009), in which a holistic system analysis of the problem of vocational training of the unemployed in USA was conducted, the theoretical and methodological principles of adult education development in American experience are revealed. Valuable in this study is that the author considered the main requirements of the labor market for the vocational training of the unemployed, as well as the directions of ensuring social protection and employment of this category of population in the country. In addition, the author has researched the activities of knowledge dissemination centers for the unemployed in the structure of US universities, the content characteristics of educational processes in different fields and qualifications levels in leading educational institutions that provide vocational training for the unemployed. Significant value is the investigated 
psychological and pedagogical conditions of professional activity of teaching staff for training unemployed and recommendations on the use of progressive ideas in the US experience in improving the system of vocational training of the unemployed in Ukraine at the national and regional levels, as well as at the level of employment services and educational institutions.

2) "Development of Pedagogical Education in the United States (1960-2000)" (Koshmanova, 2002), which explores the process of formation and development of pedagogical education in the USA in 1960-2000. The author has studied the leading trends and factors in the development of teacher education in the United States in this period, which predetermined the overall mechanism of its functioning as a coherent system that ensured the training of competent pedagogical staff. The value of this study is that based on the study of original sources, an analysis of the development of pedagogical education in the United States has been carried out, the process of formation and reformation of the curriculum of teacher training has been explored, modern fundamental ideas, ways of theoretical and practical training of teachers have been analyzed. A thorough analysis of teachers' training at the US Schools of Professional Development has given the author an opportunity to offer practical approaches to reforming pedagogical education in Ukraine in the economic realities of the transition to a market economy.

The work of O. M. Elbrecht (2010) studies the pedagogical experience of three countries: "Training of Managers in Higher Education Institutions of Great Britain, Canada, USA". The author analyzes the formation, development and current state of the professional training of managers in the UK, Canada and US higher education system. The influence of scientific concepts and theories has been analyzed, which served as the basis for the practical activity of teaching staff in the formation of content, the selection of forms and methods for training future managers in these countries. The modern models of managerial education in these countries are defined and their specifics, the content of terminology on education in general, higher and managerial education in particular, which will promote the transparency of the principles of functioning of educational systems. Besides the work determines the possible directions of implementation of the experience of Great Britain, Canada and the United States in training managers in higher education in Ukrainian educational practice.

It should be emphasized that in recent years there have been studies on comparative professional education of a systemic nature, which are noted by the European approaches to the methodology of conducting comparative studies and implementation of methodological objectives.

In this context, it should be noted the research of the doctoral level of N. S. Zhuravskaya "Training of Teachers of Agricultural Disciplines in Higher Educational Institutions of the Countries of the Initial Stage of Western European Integration and Great Britain" (2010), M. I. Palchuk "Trends in the Development of Professional Training Systems for Training of Personnel in the Aphere of Services in the EU Member-states" (2016), T. Y. Kristopchuk "Trends in the Development of Teacher-training in EU Member-states" (2014), S. G. Zaskaleta "Trends in the Professional Training of Specialists in the Agrarian Sector in EU Member-states" (2015). In the last two studies, for the first time in the Ukrainian scientific space, the concept of a monographic study, which is considered as the study of the selected aspect in a particular country, is introduced for the first time and serves as the first step before actually comparing the selected phenomenon in several countries. 
In general, the analysis of problems studied within comparative professional education gives leave to make conclusion that such studies increasingly acquire the character of comparative ones. It should be emphasized that the specifics of comparative professional education require an multidisciplinary approach to such research. That is why the effectiveness of professional comparative education, in our opinion, is determined not only by the implementation of well-known requirements for the comparator (knowledge of the language, stay in the country that is under analysis, knowledge of the history and culture of the country under study), but also ownership of the methodology of interdisciplinary research.

Namely a new scientific trend that is actively developing in Ukraine as a direction of integrated study of education - Educology allows to analyze the educational phenomena and processes on the interdisciplinary, multidisciplinary and transdisciplinary levels, in particular, the problems of professional training, to identify the dominant development of education, factors influencing the functioning of the educational system, its subsystems, as well as mechanisms of interaction and mutual influence of the institute of education with other social institutions.

Educology appeares due to the necessity of objectification on the philosophical, general scientific, specifically scientific and technological levels of complex process of functioning of the modern educational sphere; complications of processes and phenomena covered by the concept of "education"; the expansion of the problem field of educational research and its intersection with other branches of scientific knowledge (economics, political science, sociology, etc.) that are not tangent to pedagogy, but without which it is impossible to create a coherent idea of the development of the field of education in the broad sense of the concept.

Among the important tasks in the field of education as an independent scientific area, there are the following ones: studies of the sphere of education in different aspects, dimensions, relations and interrelationships with other society fields in order to identify patterns and trends in the development of education; description and comparison of various educational systems in order to highlight general characteristics and their peculiarities (Ognevjuk \& Sysoieva, 2012). The above-mentioned tasks coincide with those solved by a comparativist, examining the experience of professional training in foreign countries, since any comparative study is contextual. Successful solving of these tasks is possible on the basis of the use of a combination of scientific methods of social and humanitarian sciences, and, therefore, on the basis of an interdisciplinary approach to the study of complex and complex processes. It should be noted that this approach reflects the general tendency of modern science to strengthen the integration of disciplinary knowledge, mutual influence and interpenetration of different branches of scientific knowledge in the study of complex research object. It is the fact that the methodology of Educology, depending on the level of complexity of the educational phenomenon, is multidisciplinary or transdisciplinary allows to look at the methodology of research in the field of professional comparative education from another research perspective.

It can be stated that Educology provides methodological conditions for the development of professional comparative education, namely (Sysoieva, 2015):

- any phenomenon of professional education can be studied in a wide context field using methods of other sciences in accordance with the purpose of the study;

- the equivalence of the selected countries for research is ensured through the 
analysis of socioeconomic and cultural-historical factors affecting the development of the sphere of education and reflected in all its subsystems and components;

- increasing the likelihood of comparative research influences conclusions for educational policy, reforming and modernizing educational systems and their subsystems;

- the prognostic function of comparative research is realized, especially in that part, which explains the possibility of transferring educational innovations and models of one country to another, taking into account its tradition, culture, history, etc.;

- the preconditions are created for the formation of the theory of education, the theory of the school, its variational models and factors of influence that promote their implementation on different socio-economic, cultural and historical grounds;

- it is possible to systematically consider factors influencing the development of education as a process and result.

The latter position is of fundamental importance, since in conducting comparative studies, in particular within professional education, it is necessary to take into account external influences on educational systems, phenomena and processes that are determined by economic, historical, national, demographic, state-political and social peculiarities in the country. Economic factors determine the material possibilities of the state budget, which can be directed to the development of education, quantitative and qualitative request for graduates. Historical and national factors are closely related to the specifics and nature of society, its history and culture. These factors are most clearly manifested in the course of changes in education, the pursuit of educational reforms as a historically determined orientation of national traditions. The process of expanding access to education, introducing changes in education, educational reforms, and defining tasks for education are closely linked to demographic factors. Factors conditioned by the political system, directly affect the formation and content of educational policy. Social factors are related to the structure of society, its changes, as well as the influence of these changes on the education system.

Educology as a scientific field integrating science of education (economy of education, sociology of education, culture of education, history of education, educational policy, etc.) allows to take into account the above factors in the research of comparative education, in particular, professional. As an example, we can cite the recent two studies on comparative professional education at the Ph.D. level, which demonstrate the possibility of applying an educational approach. This study: "Professional training of experts in education in the countries of Eastern Europe" (Trygub, 2017) and "Professional training of experts in education in the German-speaking countries of the European Union" (Ponomarenko, 2017). It should be emphasized that the study of such an important problem for Ukraine became possible due to the analysis of all socio-economic and legislative processes taking place in the studied countries and the consideration of the corresponding mechanisms of interaction of the sphere of education with other spheres of society. In this context, also deserves attention the monographic study by N. V. Mospan "Higher education and the labour market in the European Union: trends of interaction" (2018), performed on the principles of Educology.

It should be noted that the existence of a large number of specialties, which pedagogical science in Ukraine is classified, make impossibile a clear demarcation of research within professional education. Studies on university education, continuing education, and VET in other countries are generally considered beyond the scope of comparative ptofessional education. 


\section{CONCLUSIONS}

1. Comparative education in Ukraine is a young branch of educational science, which began to develop actively after Ukraine gained its independence. Currently, comparative education, in particular, professional, is at the stage of formation, which is confirmed by the prevalence of descriptive studies on one foreign country over studies that are actually comparable with a strong evidence-based methodological base, with thorough generalizations and conclusions.

2. It should be emphasized that the question of the methodology of conducting comparative studies is a weak link in the studies of Ukrainian comparativists. Actual is the study of the experience of the European countries and the USA regarding the methodology of conducting comparative education studies.

3. The subject of comparative education covers all levels of education, all types of education (formal, informal, informal) and any other educational phenomena and processes, and therefore often goes beyond the boundaries of educational science and it cannot be investigated solely within disciplinary approach. This becomes of great relevance for comparative professional education.

4. Comparative professional education should develop in an multidisciplinary direction, otherwise it will constantly face disciplinary (both theoretical and methodological) barriers, which will undoubtedly hinder its development. That is why we consider it necessary to increase attention to the application of the multidisciplinary approach in the research of professional comparative education.

5. In Ukraine, there is a lack of associations or societies of educational comparative studies that would coordinate comparative studies, in particular in the field of professional education, in the country, establish cooperation with other institutions of the research infrastructure of Europe, the USA. Canada, etc., systematically hold scientific and practical conferences, seminars, discussion platforms, etc.

6. It is worth noting that the conclusions of comparative studies are left only conclusions of the dissertations, and are practically not used in the development of political decisions in the field of education, the development of the principles of reforming and modernizing education in the country. We consider it is necessary to create a system for familiarization of the competent authorities responsible for the formation of educational policy in Ukraine, with important conclusions of comparative studies, in particular, of doctoral level.

\section{REFERENCES}

Abashkina, N. V. (1999). Rozvytok profesiinoi osvity v Nimechchyni (kinets XIX - XX st.) : avtoref. dys. ... d-ra ped. nauk: spets. 13.00.04 "Teoriia i metodyka profesiinoi osvity". [Development of vocational education in Germany (late 19-20)] (Extended abstract of Doctor's thesis). Kyiv.

Bidyuk, N. M. (2009). Teoriia i praktyka profesiinoho navchannia bezrobitnykh u SShA : dys. ... $d$-ra ped. nauk: 13.00.04 [Theory and practice of vocational training of the unemployed in the USA] (PhD Thesis). Kyiv.

Christopchuk, T. E. (2014). Tendentsii rozvytku pedahohichnoi osvity v krainakh Yevropeiskoho Soiuzu : dys.... d-ra ped. nauk: 13.00.04 [Trends in the development of pedagogical education in EU member-states] (PhD Thesis). Kyiv.

Chulkova, L. O. (2010). Teoriia i praktyka pidhotovky vchytelia do pedahohichnoho spilkuvan- 
nia $u$ vyshchykh navchalnykh zakladakh Nimechchyny : avtoref. dys. ... d-ra ped. nauk: 13.00.04 "Teoriia i metodyka profesiinoi osvity" [Theory and practice of teacher training for pedagogical communication in higher educational institutions in Germany] (Extended abstract of Doctor's thesis). Kyiv.

Desyatov, T. M. (2006). Tendentsii rozvytku neperervnoi osvity v krainakh Skhidnoi Yevropy (druha polovyna XX stolittia) : dys. ... d-ra ped. nauk : 13.00.01 [Trends in Continuing Education in Eastern Europe (second half XX)] (PhD Thesis). Kyiv.

Elbrekht, O. M. (2010). Pidhotovka menedzheriv u vyshchykh navchalnykh zakladakh Velykoi Brytanii, Kanady, SShA : dys.... d-ra ped. nauk: 13.00.04. [Training for Managers in Higher Education Institutions in the UK, Canada, USA] (PhD Thesis). Kyiv.

Kaplun, A. V. (2011). Rozvytok system pidhotovky kvalifikovanykh robitnykiv u Bolharii i Polshchi (kinets KhIKh-KhKh st.) : dys... d-ra ped. nauk: 13.00.04 [Development of training systems for skilled workers in Bulgaria and Poland (end of the nineteenth and twentieth centuries)] (PhD Thesis). Kyiv.

Kedrovich, G. (2001). Teoriia i praktyka zastosuvannia kompiuternykh tekhnolohii u zahalnoosvitnikh i profesiinykh zakladakh Polshchi : dys.... d-ra ped. nauk: 13.00.04 [Theory and practice of computer technologies in general and professional institutions of Poland] (PhD Thesis). Kyiv.

Komparatyvistyka u sferi osvity: navch. prohr. dlia spetsialnostei 8.18010021 "Pedahohika vyshchoi shkoly", 8.18010020 "Upravlinnia navchalnym zakladom" (osvitno-kvalifikatsiinyi riven "mahistr" (2014) [Comparative Studies in Education: Teaching. program for specialties 8.18010021 "Pedagogics of higher education”, 8.18010020 „Management of educational institution” (educational and qualification level „Master”] (ed. Sysoieva S. O.). Kyiv: LLC Publishing Edelweiss Company, 106.

Koshmanova, T. S. (2002). Rozvytok pedahohichnoi osvity u SShA (1960 - 2000 rr.) : dys. ... d-ra ped. nauk: 13.00.04 [Development of pedagogical education in the USA $(1960-2000)$ ] (PhD Thesis). Kyiv.

Kuchay, O. V. (2016). Teoretychni i metodychni zasady pidhotovky maibutnikh uchyteliv pochatkovykh klasiv u vyshchykh navchalnykh zakladakh Polshchi zasobamy multymediinykh tekhnolohii [Theoretical and methodological principles of future primary school teachers training in higher educational institutions of Poland by means of multimedia technologies] (PhD Thesis). Cherkasy.

Leshchenko, M. P. (1996). Tekhnolohii pidhotovky vchyteliv do estetychnoho vykhovannia za rubezhem (na materialakh Velykobrytanii, Kanady, SShA) [Technologies of teacher training for aesthetic education abroad (on materials from Great Britain, Canada, USA)] (PhD Thesis). Kyiv.

Lokshyna, O. I. (2011). Tendentsii rozvytku zmistu shkilnoi osvity v krainakh Yevropeiskoho Soiuzu: avtoref. dys. ... d-ra ped. nauk : 13.00.01 "Zahalna pedahohika ta istoriia pedahohiky" [Trends in the development of the content of school education in the countries of the European Union] (Extended abstract of Doctor's thesis). Kyiv.

Moritz, J. (2004). Systema profesiinoi pidhotovky vchytelia i shliakhy yii optymizatsii v umovakh rozvytku suchasnoi osvity $v$ Polshchi: $d y$ s.... $d$-ra ped. nauk: 13.00.04 [The system of teacher training and ways of its optimization in the conditions of development of modern education in Poland] (PhD Thesis). Kyiv.

Mospan, N. V. (2018). Vyshcha osvita i rynok pratsi v Yevropeiskomu Soiuzi: tendentsii vzaiemodii [Higher education and the labour market in the European Union: trends in interaction: Monograph]. Kyiv: Edelweiss publishing house LLC. (in Ukrainian) 
Mukan, N. V. (2011). Profesiinyi rozvytok uchyteliv zahalnoosvitnikh shkil u systemakh neperervnoi pedahohichnoi osvity Velykoi Brytanii, Kanady, SShA : dys. ... d-ra ped. nauk: 13.00.04 [Professional Development of Secondary School Teachers in Continuing Teaching Education Systems of the United Kingdom, Canada, USA] (PhD Thesis). Kyiv.

Musketa, R. (2007). Pidhotovka vchyteliv fizychnoho vykhovannia u Polshchi do otsiniuvannia navchalnykh dosiahnen uchniv : dys. ... d-ra ped. nauk : 13.00.04 [Training of physical education teachers in Poland to assess student' learning achievements] (PhD Thesis). Ternopil.

Ogienko, O. I. (2009). Tendentsii rozvytku osvity doroslykh u skandynavskykh krainakh (druha polovyna XX stolittia) : avtoref. dys. ... d-ra ped. nauk: 13.00.01 "Zahalna pedahohika ta istoriia pedahohiky" [Trends in the development of adult education in Scandinavian countries (second half of the twentieth century)] (Extended abstract of Doctor's thesis). Kyiv.

Ognevyuk, V. O. \& Sysoieva, S. O. (2012). Osvitolohiia - naukovyi napriam intehrovanoho doslidzhennia sfery osvity [Education is a scientific direction of the integrated study of education]. Ridna shkola Journal, 4/5, 44-51.

Palchuk, M. I. (2016). Tendentsii rozvytku system profesiinoi pidhotovky vyrobnychoho personalu sfery posluh u krainakh Yevropeiskoho Soiuzu : dys.... d-ra ped. nauk: 13.00.04 [Trends in the development of vocational training systems for production personnel in the services sector in EU member states] (PhD Thesis). Kyiv.

Ponomarenko, N. G. (2017). Pidhotovka ekspertiv z osvity v nimetskomovnykh krainakh Yevropeiskoho Soiuzu: dys. ... kand. ped. nauk: 13.00.04 [Training of Education Experts in German-speaking Countries of the European Union] (PhD Thesis). Kyiv.

Pukhovskaya, L. P. (1998). Profesiina pidhotovka vchyteliv u krainakh Zakhidnoi Yevropy $v$ druhii polovyni XX stolittia : dys... d-ra ped. nauk: 13.00.04 [Professional training of teachers in the countries of Western Europe in the second half of the twentieth century] (PhD Thesis). Kyiv.

Robocha prohrama navchalnoi dystsypliny "Metodolohiia porivnialnykh doslidzhen u sferi osvity" dlia zdobuvachiv vyshchoi osvity (stupin "Doktor filosofii") (2018) [Work program of the educational discipline "Methodology of comparative studies in the field of education" for applicants of higher education (Ph.D. degree)] (eds. Sysoieva S. O. \& Grischuk Yu. V.). Kyiv: Edelweiss Publishing Company LLC, 20.

Sbrueva, A. A. (2005). Tendentsii reformuvannia serednoi osvity rozvynenykh anhlomovnykh krain $v$ konteksti hlobalizatsii (90-ti rr. XX - pochatok XXI st.) : avtoref. dys. ... d-ra ped. nauk: 13.00.01 "Zahalna pedahohika ta istoriia pedahohiky" [Trends in the reform of secondary education in developed English-speaking countries in the context of globalization (90s XX - early XXI)] (Extended abstract of Doctor's thesis). Kyiv.

Shandruk, S. I. (2013). Systema profesiinoi pidhotovky vchyteliv serednoi shkoly u Spoluchenykh Shtatakh Ameryky: dys. ... d-ra ped. nauk: 13.00.04 [High School Teacher Training System in the United States] (PhD Thesis). Zaporizhzhia.

Shemprukh, I. (2001). Tendentsii rozvytku pedahohichnoi osvity vchyteliv u Polshchi (1918-1999 rr.) : dys. ... d-ra ped. nauk: 13.00.04 [Trends in Teacher Education in Poland (1918-1999)] (PhD Thesis). Ivano-Frankivsk.

Sysoieva, S. O. (2015). Porivnialna pedahohika v konteksti rozvytku osvitolohii: Porivnialna pedahohika: metodolohichni oriientyry ukrainskykh komparatyvistiv: khrestomatiia/avtorskyi kolektyv [Comparative pedagogy in the context of the development of education: Comparative pedagogy: methodological benchmarks of Ukrainian comparativists: textbook / author's collective]. Kyiv: Pedahohichna dumka, 132-141. (in Ukrainian) 
Trygub, I. I. (2017). Profesiina pidhotovka ekspertiv u haluzi osvity u krainakh Skhidnoi Yevropy: $d y s$.... kand. ped. nauk: 13.00.04 [Professional training of experts in education in the countries of Eastern Europe] (PhD Thesis). Kyiv.

Vasilyuk, A. V. (2011). Tendentsii reformuvannia shkilnoi osvity Polshchi (XX - pochatok XXI st.) : avtoref. dys. ... d-ra ped. nauk: spets. 13.00.01 "Zahalna pedahohika ta istoriia pedahohiky" [Trends in the reform of school education in Poland (XX - early XXI)] (Extended abstract of Doctor's thesis). Ternopil.

Zaskalete, S. G. (2015). Tendentsii profesiinoi pidhotovky fakhivtsiv ahrarnoi haluzi v krainakh Yevropeiskoho Soiuzu : avtoref. dys. ... d-ra ped. nauk: spets. 13.00.04 "Teoriia i metodyka profesiinoi osvity" [Trends in the professional training of specialists in the agrarian sector in the countries of the European Union] (Extended abstract of Doctor's thesis). Vinnytsa.

Zhuravskaya, N. S. (2010). Pidhotovka vykladachiv ahrarnykh dystsyplin u vyshchykh navchalnykh zakladakh krain pochatkovoho etapu zakhidnoievropeiskoi intehratsii $i$ Velykobrytanii : dys. ... d-ra ped. nauk : 13.00.04. [Training of teachers of agrarian disciplines in higher educational institutions of the countries of the initial stage of Western European integration and Great Britain] (PhD Thesis). Kyiv. 